\title{
Impaired insulin-like growth factor I-mediated stimulation of glucose incorporation into glycogen in vivo in the ob/ob mouse
}

\author{
M.A.Cascieri ${ }^{1}$, E.E.Slater ${ }^{1}$, P.P.Vicario ${ }^{1}$, B.G.Green ${ }^{1}$, M.L. Bayne ${ }^{2}$ and R.Saperstein ${ }^{1}$ \\ Departments of ${ }^{1}$ Biochemical Endocrinology and ${ }^{2}$ Growth Factor Research, \\ Merck Sharp and Dohme Research Laboratories, Rahway, New Jersey, USA
}

\begin{abstract}
Summary. The ability of insulin to modulate glucose metabolism is impaired in insulin resistant ob/ob mice. It has been shown that insulin-like growth factor I stimulates the uptake and metabolism of glucose in muscle through the insulin-like growth factor receptor not the insulin receptor. Thus, we have compared the abilities of insulin-like growth factor I and insulin to stimulate the in vivo incorporation of $\left[{ }^{14} \mathrm{C}\right]$-glucose into glycogen in the diaphragm of ob/ob mice and their lean littermates. The animals used in these studies were 12-14 weeks old and the serum insulin levels of the ob/ob mice were 16-fold higher than in their lean littermates. There were no differences in the serum levels of glucose or insulinlike growth factor I. Both insulin and insulin-like growth factor I stimulate the incorporation of $\left[{ }^{14} \mathrm{C}\right]-$ glucose into glycogen in lean mice. Significant stimulation occurs at doses as low as $1 \mu \mathrm{g} / \mathrm{kg}$ of either peptide. The effective doses of insulin and insulin-like growth factor I are quite similar, which indicates that the effect of insulin-like growth factor I is mediated by the insulin-like growth factor receptor and not the insulin receptor. In contrast, greater than $100 \mu \mathrm{g} / \mathrm{kg}$ of insulin-like
\end{abstract}

growth factor I is required to stimulate $\left[{ }^{14} \mathrm{C}\right]$-glucose incorporation into glycogen in the diaphragm of ob/ob mice. Thus, $\mathrm{ob} / \mathrm{ob}$ mice are resistant to the action of both insulin and insulin-like growth factor I. In contrast to the decrease in the number of insulin receptors which occurs in ob/ob mice, there is no significant difference in the number of type 1 insulin-like growth factor receptors or in their affinity for insulin-like growth factor $I$ in muscle membranes prepared from lean and $\mathrm{ob} / \mathrm{ob}$ mice. In addition, the ability of insulin-like growth factor I to stimulate the catalysis of $\mathrm{Val}^{5}$-angiotensin II phosphorylation by the partially purified muscle type 1 insulin-like growth factor receptor is not decreased in ob/ob mice as compared with their lean littermates. These data indicate that the loss in sensitivity of the ob/ob mouse of both insulin and insulin-like growth factor I is most likely mediated by a post-receptor defect in metabolism and not by receptor down-regulation or desensitisation.

Key words: Insulin-like growth factor I, insulin-resistance, $\mathrm{ob} / \mathrm{ob}$ mice, glycogen synthesis.
The autosomal recessive mutation which is expressed as the ob/ob syndrome in mice is responsible for obesity, hyperphagia, hyperinsulinaemea and insulin resistance $[1,2]$. Because of these properties, these animals are often used as a model for Type 2 (non-insulin-dependent) diabetes in humans. Plasma membranes from insulin-responsive tissues of these mice contain reduced numbers of insulin receptors $[3,4]$. Those receptors remaining are fully functional insulin receptors as measured by the kinetics of insulin binding [5] and by tyrosine kinase activation [6]. It is not clear to what extent the insulin resistance of the ob/ob mice may be mediated by this loss in cell surface insulin receptors.

Insulin-like growth factor I (IGF I) is a 70 amino acid peptide with a high degree of structural homology to insulin [7]. Several studies have shown that IGF I stimulates glucose transport and glycogen metabolism in muscle tissue [8-10] at concentrations which suggest that the effect is mediated by the type 1 IGF receptor and not the insulin receptor. In addition, in the non-fusing muscle cell line, $\mathrm{BC} 3 \mathrm{H} 1$, preincubation with insulin $(5 \mathrm{nmol} / \mathrm{l})$ decreases the number of cell surface insulin receptors without altering the number of type 1 IGF receptors [11]. Glucose transport in these insulin-treated cells is not increased by subsequent treatment with insulin, but is stimulated by IGF I at the same doses as non-treated cells [11]. Thus, the effects of IGF I cannot be mediated by the insulin receptor.

These experiments suggest that the evaluation of the effects of IGF I on glucose metabolism in muscle tissue of ob/ob mice may be useful in determining if the insulin resistance is due solely to a loss in cell surface insulin receptors. We have recently described the purification and characterisation of fully biologically active 


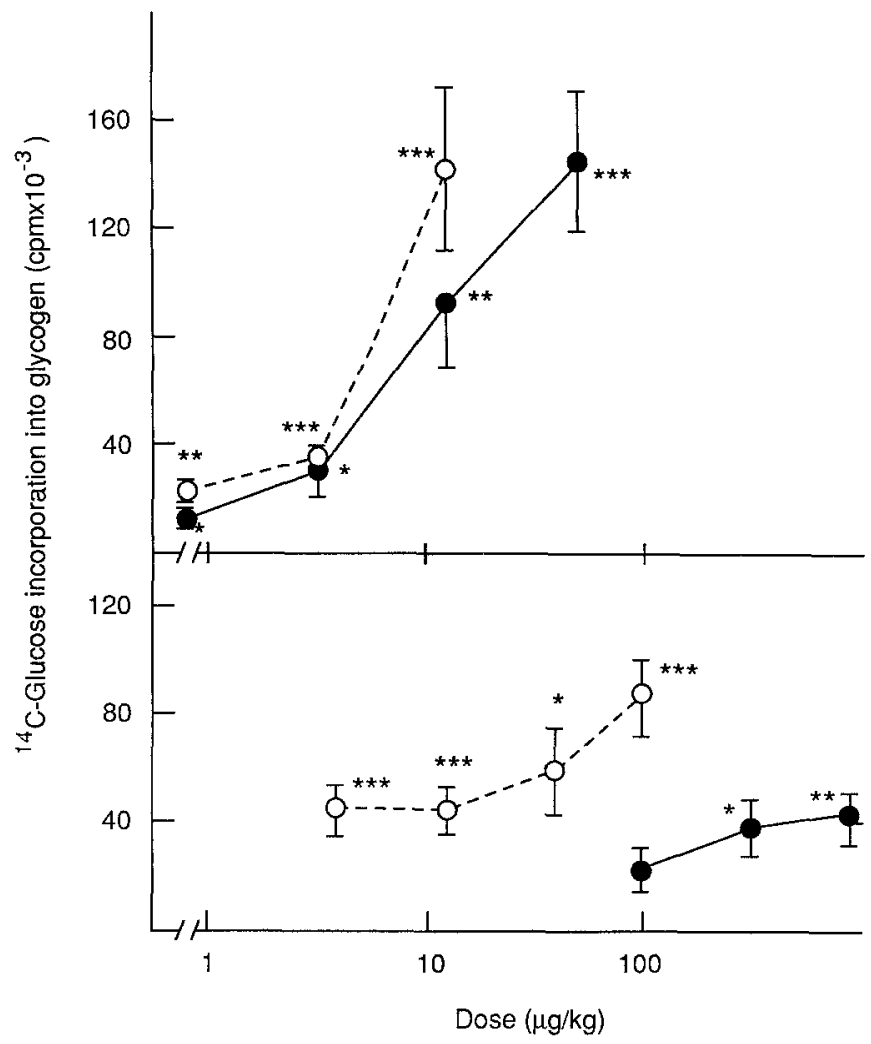

Fig. 1. Incorporation of $\left[{ }^{14} \mathrm{C}\right]$-glucose into glycogen in the diaphragm

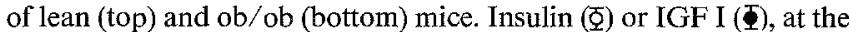
doses indicated, were injected intraperitoneally along with $\left[{ }^{14} \mathrm{C}\right]-\mathrm{glu}$ cose as described in the Methods section. After $2 \mathrm{~h}$, animals were killed, the diaphragm was removed, and the incorporation of radioactivity into total glycogen was determined. Data points are normalised for wet tissue weight and are the means \pm SEM for 5 animals. Relative potencies were determined by the parallel line bioassay technique [21]. The data were analysed by unpaired t-test- and points which are significantly different from control animals (no peptide) are noted. The values for control animals are $6608 \pm 797 \mathrm{cpm}$ for lean mice and $4358 \pm 2918 \mathrm{cpm}$ for ob/ob mice. * $p<0.05, * * p<0.01, * * * p<0.001$

IGF I from the conditioned media of yeast [12] transformed with a vector containing a synthetic gene for IGF I [13]. In the experiments reported here, we have used this IGF I to measure its ability to stimulate the incorporation of glucose into the diaphragm of ob/ob mice and their lean littermates in vivo.

\section{Materials and methods}

Male ob/ob (C57BL/6J) mice and their lean littermates were obtained from Jackson Laboratories (Bar Harbor, Me, USA) and were fed ad libitum up to the time of experiment. $\left[{ }^{125}\right.$ I]Iodine (carrier free)

Table 1. Serum insulin, glucose, and insulin-like growth factor I (IGF I) levels in lean and ob/ob mice

\begin{tabular}{lcll}
\hline & Insulin $^{\mathrm{a}}$ & Glucose $^{\mathrm{a}}$ & IGF I $^{\mathrm{a}}$ \\
\hline & $(\mathrm{ng} / \mathrm{ml})$ & $\mathrm{mg} / \mathrm{dl}$ & $(\mathrm{ng} / \mathrm{ml})$ \\
Lean & $0.62 \pm 0.05$ & $136 \pm 11$ & $163 \pm 14$ \\
ob/ob & $10.6 \pm 0.5$ & $121 \pm 8$ & $192 \pm 35$ \\
\hline
\end{tabular}

a mean $\pm S D$ for 10 determinations was from Amersham Corp (Arlington Heights, Ill, USA). $\left[\gamma^{32} \mathrm{P}\right]-\mathrm{ATP}$ $(2900 \mathrm{Ci} / \mathrm{mmol})$ and $\left[\mathrm{U}^{14} \mathrm{Cl}\right.$-glucose $(13.5 \mathrm{mCi} / \mathrm{mmol})$ were from DuPont NEN (Boston, Mass, USA). Val ${ }^{5}$-Angiotensin II was from Vega Biotechnologies (Tucson, Ariz, USA). IGF I was purified from the conditioned media of yeast transformed with a vector containing a synthetic gene for IGF I as previously described [12]. The purity of the peptide was confirmed by SDS-polyacrylamide gel electrophoresis and silver staining performed as previously described [14], and it is fully biologically active compared with authentic human IGF I [12].

\section{Determination of in vivo stimulation of muscle glycogen synthesis}

The method has been described in detail by Rafaelson $[15,16]$. Briefly, $\left[\mathrm{U}^{14} \mathrm{C}\right]$ glucose $(0.6 \mu \mathrm{Ci})$ and peptide were injected i.p. in saline containing $0.1 \%$ bovine serum albumin (BSA) into fasted $(18 \mathrm{~h})$ male mice. After $2 \mathrm{~h}$, the mice were killed, the hemidiaphragms were removed, weighed, and the incorporation of $\left[{ }^{14} \mathrm{C}\right]$ glucose into total glycogen was determined.

\section{IGF I binding to muscle membranes}

${ }^{125}$ I-IGF I (50-80 Ci/g) was prepared as described previously [11]. Hind limb skeletal muscle plasma membranes were prepared as described by Schmid-Antomarchi et al. [17]. Briefly, tissue was removed and homogenised using a Polytron PT-35 (Brinkmann, Westbury, NY, USA) in 10 volumes of $5 \mathrm{mmol} / 1$ Tris, $\mathrm{pH} 7.5 \mathrm{con}$ taining $0.25 \mathrm{~mol} / 1$ sucrose and $1 \mathrm{mmol} / 1$ EDTA. The homogenate was centrifuged at $1500 \times \mathrm{g}$ for $15 \mathrm{~min}$, and the supernatant was centrifuged at $10,000 \times g$ for $20 \mathrm{~min}$. The supernatant was centrifuged at $100,000 \times g$ for $1 \mathrm{~h}$. This pellet was resuspended in the assay buffer at a concentration of approximately $20 \mathrm{mg}$ protein $/ \mathrm{ml}$. The specific activity of $5^{t}$ nucleotidase in the membrane preparations was determined using the method described by Avruch and Wallach [18]. ${ }^{125} \mathrm{I}-$ IGF I $(0.25 \mathrm{nmol} / \mathrm{l})$ and membranes $(0.2 \mathrm{mg})$ were incubated in the presence and absence of competing IGF I $(0.3 \mu \mathrm{mol} / \mathrm{l})$ in $0.2 \mathrm{ml}$ Hepes, pH 8 containing $120 \mathrm{mmol} / 1 \mathrm{NaCl}, 5 \mathrm{mmol} / 1 \mathrm{KCl}$, $0.12 \mathrm{mmol} / 1 \mathrm{MgSO}_{4}$, and $0.1 \% \mathrm{BSA}$ for $1 \mathrm{~h}$ at $20^{\circ} \mathrm{C}$. Samples were filtered over Whatman GF/F filters pre-soaked in $0.1 \%$ polyethyleneimine to separate bound from free ligand. The incubation tubes and filters were washed four times with $2.5 \mathrm{ml}$ cold assay buffer (minus BSA). Less than 5\% of the ligand bound to the filters in the absence of competing peptides. Muscle membranes bound $25 \%$ of the ligand in the absence of competing peptides. Non-specific binding, measured by adding excess amounts of unlabelled IGF I $(0.3 \mu \mathrm{mol} / 1)$, was $36-44 \%$ (mean $\pm \mathrm{SD}=38.6 \pm 3.2)$ of the total binding of ligand to membranes.

\section{Insulin and IGF receptor tyrosine kinase assay}

Assays were carried out as previously described [6]. Briefly, wheat germ affinity-purified muscle preparations were incubated in the $a b$ sence or presence of peptide for $15 \mathrm{~min}$ at $23^{\circ} \mathrm{C}$, then $\left[\gamma^{32} \mathrm{P}\right]$-ATP was added for an additional $15 \mathrm{~min}$. The receptor preparations were then incubated with $\mathrm{Val}^{5}$-angiotensin II for $10 \mathrm{~min}$ at $23^{\circ} \mathrm{C}$. Phosphorylated proteins were precipitated by trichloroacetic acid, and an aliquot of the supernatant was absorbed to phosphocellulose (P81) paper. The paper was extensively washed with $75 \mathrm{mmol} / \mathrm{l} \mathrm{H}_{3} \mathrm{PO}_{4}$ to remove excess label, and counted. Results are expressed as pmol ${ }^{32} \mathrm{P}^{-V_{a l}}{ }^{5}$-angiotensin II formed per min per $\mathrm{mg}$ protein. 


\section{Other methods}

Blood glucose was measured by the Ferricyanide/Ferrocyanide oxidation-reduction method using an auto-analyzer (Technicon Corp, Tarrytown, NY, USA). Plasma insulin levels were determined by a modification of the procedure described by Herbert et al. [19]. Plasma IGF I levels were determined using antiserum UB286 (National Hormone and Pituitary Program, Baltimore, Md, USA) at a final dilution of $1: 8000$ as described by Furlanetto et al. [20] with the following modifications. Fresh plasma was incubated with an equal volume of $2 \mathrm{~mol} / \mathrm{l}$ acetic acid at room temperature for $2 \mathrm{~h}$; the extract was applied to a C18 Sep Pak (Waters Assoc, Milford, Mass, USA); the Sep Pak was washed with excess $1 \mathrm{~mol} / 1$ acetic acid; and then IGF I was eluted using methanol. The recovery of IGF I during this extraction procedure was $>95 \%$. The methanol extracts were dried and redissolved in RIA assay buffer. The extracts were incubated with antibody for one $h$ before the addition of $\operatorname{tracer}^{125}$ I-IGF I. The assay was completed as previously described [20].

\section{Statistical analysis}

Differences between experimental and control data sets were analysed by unpaired t-test as described in the Figure legends. Relative potencies were determined using the parallel line bioassay technique [21].

\section{Results}

The animals used in these experiments were $o b / o b$ mice and their lean littermates which were 12-14 weeks old. The ob/ob animals are markedly hyperinsulinaemic, with serum insulin levels 16-fold higher than their lean littermates (Table 1). The blood glucose levels in the ob/ob animals are not significantly different than in their lean littermates (Table 1). Surwit et al. have shown that when hyperglycaemia is seen in animals with the $\mathrm{ob} / \mathrm{ob}$ syndrome, it is stress-induced [22]. Serum levels of IGF I are not significantly different in the lean and ob/ob mice (Table 1).

Insulin and IGF I stimulate the incorporation of $\left[{ }^{14} \mathrm{C}\right]$-glucose into muscle glycogen in lean mice in a dose-responsive manner (Fig.1). Significant stimulation $(p<0.01$ and 0.05 , respectively) occurs at doses as low as $1 \mu \mathrm{g} / \mathrm{kg}$ insulin or IGF I. IGF I is $50 \%$ as potent as insulin in stimulating glycogen synthesis in lean animals as determined using the parallel line bioassay technique [21].

Insulin stimulates the incorporation of $\left[{ }^{14} \mathrm{C}\right]$-glucose into glycogen in ob/ob mice (Fig. 1). Significant stimulation $(p<0.001$ ) occurs at $3.3 \mu \mathrm{g} / \mathrm{kg}$ insulin. However, the degree of stimulation achieved by $10 \mu \mathrm{g} / \mathrm{kg}$ insulin in lean mice (i.e. 20-fold) requires the administration of $100 \mu \mathrm{g} / \mathrm{kg}$ insulin in the ob/ob animals (Fig. 1). In a preliminary experiment, we observed that IGF I does not stimulate in ob/ob animals at doses ranging from 3 to $100 \mu \mathrm{g} / \mathrm{kg}$. Significant stimulation $(p<0.05)$ of $\left[{ }^{14} \mathrm{C}\right]-$ glucose incorporation into glycogen requires greater than $100 \mu \mathrm{g} / \mathrm{kg}$ IGF I (Fig. 1). Thus, >30-fold higher levels of IGF I are required to stimulate muscle gly-

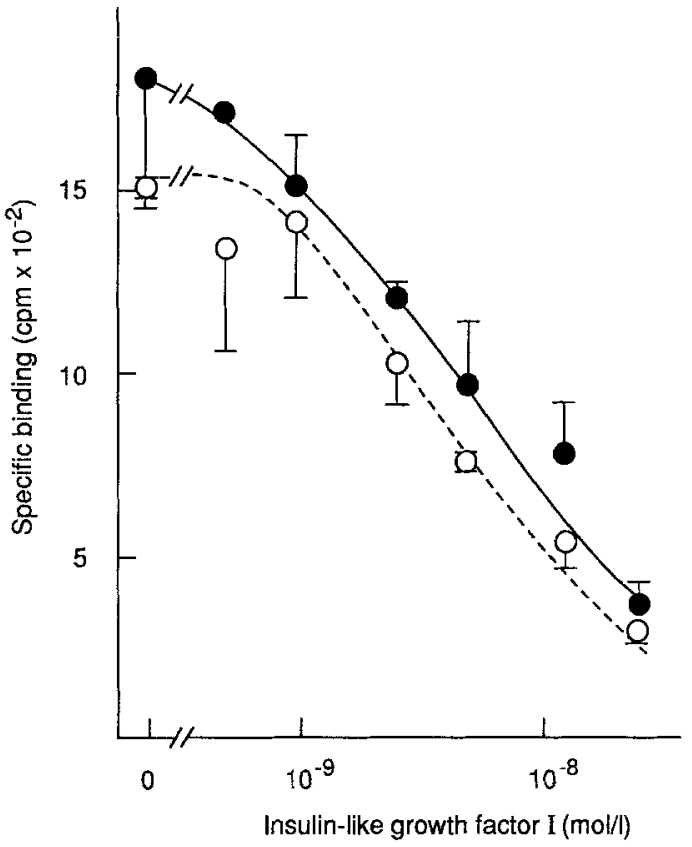

Fig. 2. ${ }^{125}$ I-IGF I binding to the type 1 IGF receptor of skeletal muscle membranes prepared from lean $(\boldsymbol{\phi})$ and ob/ob $(\$)$ mice. ${ }^{125} \mathrm{I}$ IGF I $(0.2 \mathrm{nmol} / \mathrm{l})$ was incubated with membranes $(0.25 \mathrm{mg}$ protein) in the presence and absence of unlabelled IGF I $(0.3 \mu \mathrm{mol} / 1)$ in $0.05 \mathrm{ml}$ as described in the Materials and methods section. The data represent the mean \pm SD for 2 membrane preparations and each preparation started with the hindleg muscles from 5-6 animals

cogen synthesis in ob/ob mice than in their lean littermates.

${ }^{125}$ I-IGF I $(0.25 \mathrm{nmol} / \mathrm{l})$ specifically binds to sites on membranes prepared from hindleg muscle and unlabelled IGF $I$ is able to inhibit the binding with $\mathrm{IC}_{50}=10 \pm 7$ and $6 \pm 4 \mathrm{nmol} / 1$ in membranes from lean and $\mathrm{ob} / \mathrm{ob}$ animals, respectively (mean $\pm \mathrm{SD}, n=2$, Fig. 2). There is no significant difference either in the maximal binding capacity or in the ability of IGF I to inhibit the binding to membranes prepared from lean and ob/ob mice (Fig. 2). Scatchard analysis of these data shows that the $\mathrm{K}_{\mathrm{d}}$ of type $1 \mathrm{IGF}$ receptors from lean and $\mathrm{ob} / \mathrm{ob}$ mice are $6.7 \pm 3.3$ and $6.1 \pm 4 \mathrm{nmol} / 1$, respectively (mean $\pm \mathrm{SD}, n=2$ ). The ob/ob preparations contain $30 \%$ fewer insulin receptors than the preparations from lean mice (data not shown). The specific activity of $5^{\prime}$ nucleotidase, a specific plasma membrane marker protein, is not significantly different between membranes prepared from lean and ob/ob animals, indicating that the plasma membrane content of membranes prepared from both types of animals is similar (data not shown).

Partially purified muscle membrane preparations catalyse the phosphorylation of $\mathrm{Val}^{5}$-angiotensin II (Fig.3). Insulin stimulates the catalysis by preparations from lean mice 7 and $11.1 \mathrm{pmol} \cdot \mathrm{min}^{-1} \cdot \mathrm{mg}^{-1}$ protein at 10 and $100 \mathrm{nmol} / 1$, respectively (Fig. 3). Insulin stimulates 4.4 and $7.1 \mathrm{pmol} \cdot \mathrm{min}^{-1} \cdot \mathrm{mg}^{-1}$ protein at 10 and $100 \mathrm{nmol} / 1$, respectively, in preparations from 


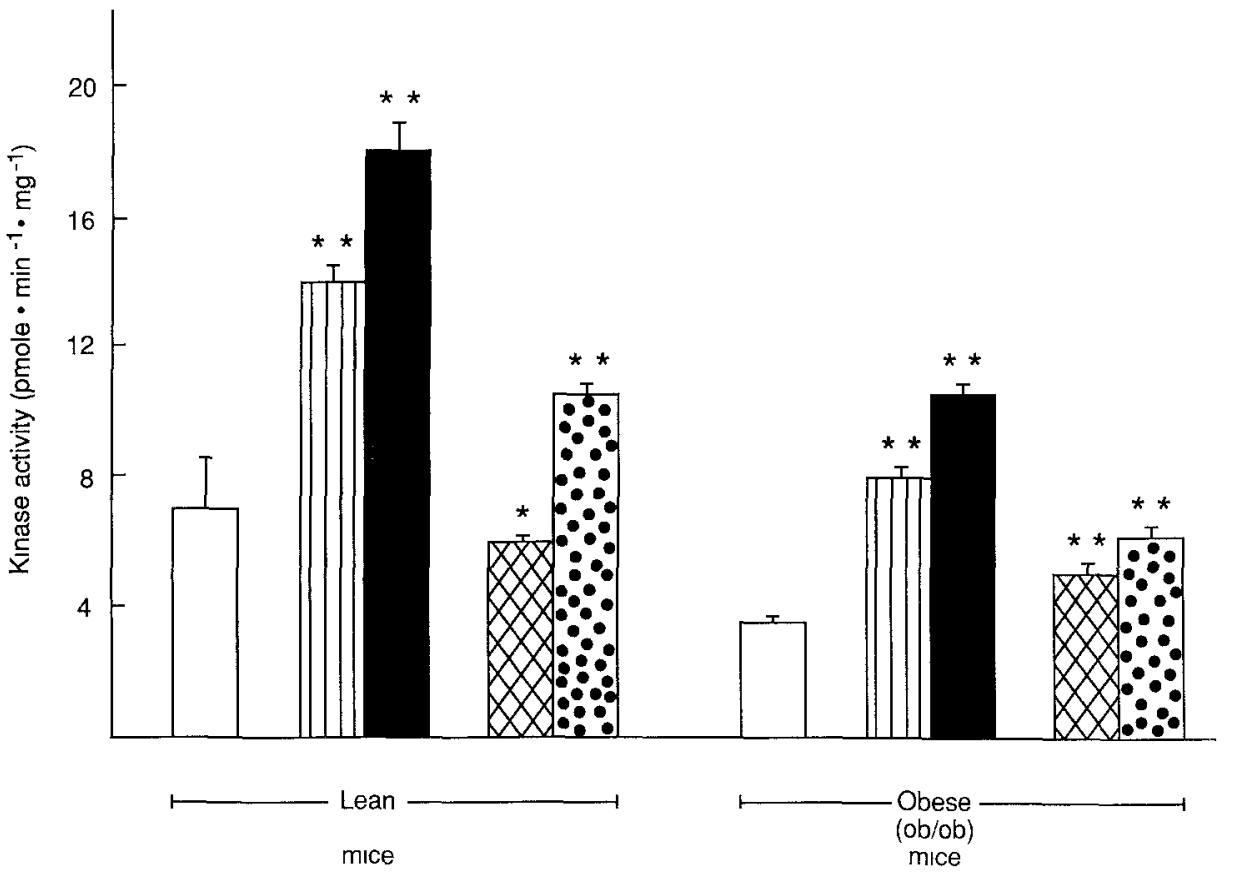

Fig. 3. Stimulation of the catalysis of Val ${ }^{5}$-angiotensin II phosphorylation by partially purified mouse skeletal muscle insulin and type 1 IGF receptors. Wheat germ affinity-purified muscle preparations $(400 \mu \mathrm{g} / \mathrm{ml})$, which contained equal amounts of ${ }^{125}$ I-IGF I binding activity per mg protein, were incubated in the presence or absence of peptide for $15 \mathrm{~min}$ at $23^{\circ} \mathrm{C}$, then an additional $15 \mathrm{~min}$ with $\left[\gamma^{32} \mathrm{P}\right]-\mathrm{ATP}(50 \mu \mathrm{mol} / 1$, $1 \mu \mathrm{Ci})$. The ability of the preparation to catalyse the phosphorylation of $\mathrm{Val}^{5}$-angiotensin II was measured during a 10 min incubation at $23^{\circ} \mathrm{C}$. Data are expressed as the mean \pm SD for 3 determinations. The data were analysed by unpaired t-test in order to determine if the kinase activity in the presence of peptide was significantly different from the basal values. . $\bar{d}=$ basal, 面 $=10 \mathrm{nmol} / 1 \mathrm{in}$ sulin, $\mathbf{T}=100 \mathrm{nmol} / 1 \mathrm{insulin}$, 䃯= $10 \mathrm{nmol} / 1 \mathrm{IGF}$ I, $=100 \mathrm{nmol} / 1 \mathrm{IGF}$ I. * not significant at $p=0.05$,

** significantly different at $p<0.05$ $\mathrm{ob} / \mathrm{ob}$ mice. This $38 \%$ decrease in the responsiveness of $\mathrm{ob} / \mathrm{ob}$ mice compared to lean mice is due to a decrease in the number of insulin receptors per $\mathrm{mg}$ protein in the $\mathrm{ob} / \mathrm{ob}$ muscle preparations [6].

IGF I $(100 \mathrm{nmol} / \mathrm{l})$ stimulates $3.5 \mathrm{pmol} \cdot \mathrm{min}^{-1}$. $\mathrm{mg}^{-1}$ protein in preparations from lean mice, although there is no significant stimulation by $10 \mathrm{nmol} / 1 \mathrm{IGF}$ I. In preparations from ob/ob mice, IGF I stimulates 1.6 and $2.8 \mathrm{pmol} \cdot \mathrm{min}^{-1} \cdot \mathrm{mg}^{-1}$ protein at 10 and $100 \mathrm{nmol} / 1$, respectively (Fig. 3).

\section{Discussion}

IGF I stimulates the incorporation of $\left[{ }^{14} \mathrm{C}\right]$-glucose into glycogen in the mouse diaphragm with 2-fold lower potency than insulin. This is similar to previous observations in mouse soleus muscle [8,9], in rat heart [10,23] and in a muscle cell line [11]. Since IGF I has at least 30fold lower affinity than insulin for muscle insulin receptors [11], the stimulation by IGF I is likely mediated by an IGF receptor in this tissue and not by the insulin receptor. IGF I is also 2-fold less potent than insulin in stimulating glucose transport in perifused rat heart $[10$, 23] and in BC3H1 cells [11]. In contrast, Poggi et al. showed that IGF I was 20 -fold less potent than insulin in stimulating glucose transport in isolated mouse soleus muscle [8]. The reason for this quantitative difference is not known, although it has recently been demonstrated that the potency of IGF I in a given biological assay system is controlled by the levels of its receptor, as well as by levels of tissue-derived IGF binding proteins $[24,25]$. Thus, both the types and quantities of binding proteins secreted by a tissue will affect the potency of IGF I.
IGF I interacts with two types of receptors that differ both in their physical properties and in their affinities for IGF I, IGF II, and insulin [26-28]. Since it has recently been observed by several groups that synthetic and recombinantly-produced IGF I have very low affinity for type 2 IGF receptors $[12,29,30]$, it is likely that the effects of IGF I are mediated by the type 1 IGF receptor.

Our data, as well as that of other researchers $[1,2]$, suggest that $\mathrm{ob} / \mathrm{ob}$ animals are resistant to the action of insulin. In contrast to the sensitivity of the lean mice to IGF I, $>30$-fold higher levels of IGF I are required to see significant stimulation of $\left[{ }^{14} \mathrm{C}\right]$-glucose incorporation into muscle glycogen in the ob/ob mice. Thus, $\mathrm{ob} / \mathrm{ob}$ mice are resistant to the action of both insulin and IGF I. In fact, the sensitivity of diaphragm glycogen synthesis to IGF I in ob/ob mice may be reduced further than the sensitivity to insulin. However, the maximal response to either peptide was not achieved at the doses administered to the ob/ob mice, and so it is not possible to quantitatively assess the relative potency of IGF I and insulin in ob/ob mice with the present data. These data may suggest that multiple mechanisms are involved in reducing the sensitivity of ob/ob diaphragm to IGF I, and that not all of those mechanisms may pertain to insulin action in this tissue.

Poggi et al. showed that isolated soleus muscles of goldthioglucose-obese mice required 5-fold higher levels of IGF I to stimulate glycogen synthase than muscles from lean mice [8]. The measurement of glucose incorporation into diaphragm glycogen after intraperitoneal injection of glucose and insulin was first described by Rafaelson [15]. He convincingly showed that the insulin effects were mediated by a local action within the peritoneum since blood glucose levels were not 
affected at insulin doses which gave a $400 \%$ increase in glycogen synthesis in the diaphragm [15]. Thus, this method offers the advantages of an in vivo system with some degree of isolation from the systemic circulation. This assay system offers a distinct advantage when looking at the activity of IGF I, since very large doses must be given i.v. to saturate the large pool of circulating IGF binding proteins. In contrast, we have shown that the sensitivity of the diaphragm response to IGF I after i.p. injection in rats is only reduced 4-fold compared to IGF analogue which do not bind to serum binding proteins [24].

The insulin resistance of ob/ob mice has been ascribed partially to the reduced level of insulin receptors in muscle [31] and other tissues [3-5]. This loss in receptor number is probably due to the marked hyperinsulinaemia of these animals. However, the binding properties of these receptors [5] and the tyrosine kinase activity per number of receptors [6] are normal. We have shown that the number of type 1 IGF receptors in the muscles of $\mathrm{ob} / \mathrm{ob}$ mice is not reduced, and that their tyrosine kinase activity per number of receptors is similar to that of receptors from muscle of lean mice. Thus, in contrast to their decreased number of insulin receptors, the $\mathrm{ob} / \mathrm{ob}$ animals are resistant to the action of IGF I even though the receptor levels are not reduced.

A type of insulin resistance can be induced in various cell types by preincubation with insulin. This in vitro hyperinsulinaemia induces a loss of cell surface receptors and a desensitisation of the cellular response to subsequent doses of insulin when measuring 2-deoxyglucose transport in $\mathrm{BC} 3 \mathrm{H} 1$ cells [11], glucose oxidation and metabolism in rat adipocytes [32] and glycogen synthesis in human HepG2 cells [33]. In contrast to the observations in ob/ob mice described above, the receptors remaining on adipocytes or HepG2 cells after prolonged exposure to insulin have markedly reduced tyrosine kinase activity per number of receptors $[32,33]$. Thus, the mechanisms involved in insulin-induced desensitisation in vitro are clearly different than the mechanisms causing insulin resistance in ob/ob mice.

In addition, we have shown that glucose transport in $\mathrm{BC} 3 \mathrm{H} 1$ cells pre-incubated with insulin is normally responsive to IGF I despite a 100 -fold loss in sensitivity to insulin [11]. Thus, it is possible that the insulin-induced desensitisation of the insulin receptor tyrosine kinase activity is the sole mechanism involved in the loss of insulin responsiveness in cells pretreated with insulin. We have clearly shown that this mechanism is not important in mediating insulin resistance in ob/ob mice.

Our data suggest that measuring the glucoregulatory effects of IGF I in insulin-resistant states may be a useful method to distinguish between insulin receptormediated and post-insulin receptor-mediated mechanisms of insulin resistance. It has recently been shown by Caro et al. that insulin receptors in the liver and adipose of obese humans with Type 2 diabetes have reduced tyrosine kinase activity as compared with non- diabetic, obese patients and lean control subjects [34, 35]. The ability of the tyrosine kinase activity of human skeletal muscle insulin receptors to catalyse the phosphorylation of exogenous substrates is reduced in both obese and Type 2 diabetic subjects $[36,37]$. These data suggest that the insulin resistance in Type 2 diabetes is at least partially due to defective insulin receptor tyrosine kinase. At present, it is not known if patients with Type 2 diabetes and insulin resistance are also resistant to the glucoregulatory effects of a bolus dose of IGF I.

At present, we have no evidence to suggest which step in the pathway of insulin/IGF I-induced glycogen synthesis is deficient in ob/ob diaphragm muscle. However, the data presented here strongly suggest that the insensitivity of muscle from ob/ob mice to insulin and IGF I is more than likely not due to a receptor defect but to a post-receptor abnormality in a transduction step common to the action of both peptides.

Acknowledgements. The authors would like to acknowledge Mr.E.Chapin and Ms. M. Pastor for their assistance in performing the in vivo assays. We would also like to thank Drs. L. Underwood and J.J.Van Wyk, Division of Pediatric Endocrinology, University of North Carolina at Chapel Hill, NC, USA for anti-IGF I antibody UB286 which was distributed through the National Hormone and Pituitary Program.

\section{References}

1. Herberg L, Coleman DL (1977) Laboratory animals exhibiting obesity and diabetes syndromes. Metabolism 26:59-99

2. Bray GA, York DA (1979) Genetically transmitted obesity in rodents. Physiol Rev 51: 598-646

3. Kahn CR, Neville DM, Roth J (1973) Insulin-receptor interaction in the obese-hyperglycemic mouse. J Biol Chem 248: 244-250

4. Freychet $P$, Laudat MH, Laudat P, Rosselin G, Kahn CR, Gorden $P$, Roth J (1972) Impairment of insulin binding to the fat cell plasma membrane in the obese hyperglycemic mouse. FEBS Lett 25: 339-342

5. Soll AH, Kahn CR, Neville DM (1978) Insulin binding to liver plasma membranes in the obese hyperglycemic (ob/ob) mouse. J Biol Chem 250: 4702-4707

6. Vicario P, Brady EJ, Slater EE, Saperstein R (1987) Insulin receptor tyrosine kinase is unaltered in $\mathrm{ob} / \mathrm{ob}$ and $\mathrm{db} / \mathrm{db}$ mouse skeletal muscle membranes. Life Sciences 41: 1233-1241

7. Rinderknecht E, Humbel RE (1978) The amino acid sequence of human insulin-like growth factor I and its structural homology with proinsulin. J Biol Chem 253: 2769-2776

8. Poggi C, Le Marchand-Brustel Y, Zapf J, Froesch ER, Freychet P (1979) Effects and binding of insulin-like growth factor $I$ in the isolated soleus muscle of lean and obese mice: comparison with insulin. Endocrinology 105: 723-730

9. Yu K-T, Czech MP (1984) The type 1 insulin-like growth factor receptor mediates the rapid effects of multiplication-stimulating activity on membrane transport systems in rat soleus muscle. $J$ Biol Chem 259: 3090-3095

10. Meuli C, Froesch ER (1977) Insulin and nonsuppressible insulinlike activity (NSILA-S) stimulate the same glucose transport system via two separate receptors in rat heart. Bioch Biophys Res Commun 75: 689-695

11. Cascieri MA, Chicchi GG, Hayes NS, Strader CD (1986) (Thr-59)insulin-like growth factor I stimulates 2-deoxyglucose transport in $\mathrm{BC} 3 \mathrm{H} 1$ myocytes through the insulin-like growth factor receptor, not the insulin receptor. Biochem Biophys Acta 886: 491-499 
12. Bayne ML, Applebaum J, Chichi GG, Hayes NS, Green BG, Cascieri MA (1988) Expression, purification and characterization of recombinant human insulin-like growth factor I in yeast. Gene 66: $235-244$

13. Bayne ML, Cascieri MA, Kelder B, Applebaum J, Chicchi G, Shapiro J, Pasleau F, Kopchick JJ (1987) Expression of a synthetic gene encoding human insulin-like growth factor I in cultured mouse fibroblasts. Proc Natl Acad Sci USA 84: 2638-2642

14. Gimenez-Gallego G, Navia MA, Reuben JP, Katz GM, Kaczorowski GJ, Garcia ML (1988) Purification, sequence and model structure of charybdotoxin, a potent selective inhibitor of calciumactiviated potassium channels. Proc Natl Acad Sci USA 85: 3329-3333

15. Rafaelson OJ (1964) Glycogen content of rat diaphragm after intraperitoneal injection of insulin and other hormones. Acta Physiol Scand 61: 314-322

16. Rafaelson OJ, Lauris V, Renold AE (1965) Localized intraperitoneal action of insulin on rat diaphragm and epididymal adipose tissue in vivo. Diabetes 14: 19-26

17. Schmid-Antomarchi $H$, Renaud J-F, Romey G, Hugues $M$, Schmid A, Lazdunski M (1985) The all-or-none role of innervation in expression of apamin receptor and of apamin-sensitive $\mathrm{Ca}^{2+}$-activated $\mathrm{K}^{+}$channel in mammalian skeletal muscle. Proc Natl Acad Sci USA 82: 2188-2191

18. Avruch J, Wallach DFH (1971) Preparation and properties of plasma membrane and endoplasmic reticulum fragments from isolated rat fat cells. Bioch Biophys Acta 233: 334-347

19. Herbert V, Lau KS, Gottlieb CN, Bleicher SJ (1965) Coated charcoal immunoassay of insulin. J Clin Endocrinol Met 25: 1375-1384

20. Furlanetto RW, Underwood LE, Van Wyk JJ, D'Ercole AJ (1977) Estimation of somatomedin-C levels in normals and patients with pituitary disease by radioimmunoassay. J Clin Invest 60: 648-657

21. Finney DJ (1978) Parallel line bioassay technique. In: Statistical methods in biological assay. Charles Griffin, London, pp 59-100

22. Surwit RS, Feinglos MN, Livingston EG, Kuhn CM, McCubbin JA (1984) Behavioral manipulation of the diabetic phenotype in ob.ob mice. Diabetes 33: 616-618

23. Meuli C, Froesch ER (1975) Effects of insulin and NSILA-S on the perfused rat heart: glucose uptake, lactate production and efflux of 3-O-methyl glucose. Eur J Clin Invest 5:93 99

24. Cascieri MA, Saperstein R, Hayes NS, Green BG, Chicchi GG, Applebaum J, Bayne ML (1988) Serum half-life and biological activity of mutants of human insulin-like growth factor I which do not bind to serum binding proteins. Endocrinology 123: 373 381

25. Cascieri MA, Hayes NS, Bayne ML (1989) Characterization of the increased biological potency in Balb/C 3T3 cells of two analogs of human insulin-like growth factor I which have reduced affinity for the $28 \mathrm{~K}$ cell-derived binding protein. J Cell Physiol 139: $181-188$

26. Massague J, Czech MP (1982) The subunit structures of two distinct receptors for insulin-like growth factors I and II and their relationship with the insulin receptor. J Biol Chem 257: 5038-5045
27. Ullich A, Gray A, Tam AW, Yang-Feng T, Tsubokawa M, Collins C, Henzel W, Le Bon T, Kathuria S, Chen E, Jacobs S, Francke U, Ramachandran J, Fujita-Yamaguchi Y (1986) EMBO Journal 5: 2503-2512

28. Morgan DO, Edman JC, Standring DN, Fried VA, Smith MC, Roth RA, Rutter WJ (1987) Insulin-like growth factor II receptor as a multifunctional binding protein. Nature $329: 301-307$

29. Rosenfeld RG, Conover CA, Hodges D, Lee PdK, Misra P, Hintz $\mathrm{RL}, \mathrm{Li} \mathrm{CH}$ (1987) Heterogeneity of insulin-like growth factor I affinity for the insulin-like growth factor II receptor: comparison of natural, synthetic and recombinant DNA derived insulin-like growth factor I. Bioch Biophys Res Commun 143: 199-205

30. Tally M, Enberg G, Li CH, Hall K (1987) The specificity of the human IGF-2 receptor. Biochem Biophys Res Commun 147: 1206-1212

31. Le Marchand-Brustel Y, Jeanrenaud B, Freychet P (1978) Insulin binding and effects in isolated soleus muscle of lean and obese mice. J Am Physiol Soc 78: E348-E358

32. Arsenis G, Livingston JN (1986) Alterations in the tyrosine kinase activity of the insulin receptor produced by in vitro hyperinsulinemia. J Biol Chem 261: 147-153

33. Blake AD, Hayes NS, Slater EE, Strader CD (1987) Insulin receptor desensitization correlates with attenuation of tyrosine kinase activity, but not of receptor endocytosis. Biochem J 245: 357-364

34. Caro JF, Ittoop O, Pories WJ, Meelheim D, Flickinger EG, Thomas F, Jenquin M, Silverman JF, Khazanie PG, Sinha MK (1986) Studies of the mechanism of insulin resistance in the liver from humans with noninsulin-dependent diabetes. J Clin Invest 78 : 249-258

35. Sinha M, Pories WJ, Flickinger EG, Meelheim D, Caro JF (1987) Insulin-receptor kinase activity of adipose tissue from morbidly obese humans with and without NIDDM. Diabetes 36: 620-625

36. Caro, JF, Sinha MK, Raju SM, Ittoop Ol, Pories WJ, Flickinger EG, Meelheim D, Dohm GL (1987) Insulin receptor kinase in human skeletal muscle from obese subjects with and without noninsulin dependent diabetes. J Clin Invest 79: 1330-1337

37. Arner P, Pollare T, Lithell H, Livingston JN (1987) Defective insulin receptor tyrosine kinase in human skeletal muscle in obesity and Type 2 (non-insulin-dependent) diabetes mellitus. Diabetologia $30: 437-440$

Received: 4 August 1988

and in revised form: 4 April 1989

Dr.M.A. Cascieri

Merck Sharp and Dohme Research Laboratories

$80 \mathrm{~W}-243$

P.O. Box 2000

Rahway, NJ 07065

USA 